\title{
Exploratory analyses of migration timing and morphometrics of the Pied Flycatcher (Ficedula hypoleuca)
}

\author{
Andrea Harnos ${ }^{1 *}$, Péter Fehérvári ${ }^{1,2}$, Imre Sándor Piross ${ }^{1}$, \\ Zsolt KARCZA ${ }^{3}$, Nóra ÁGH ${ }^{1}$, Szilvia KovÁCs ${ }^{4} \&$ Tibor CsÖRGÖ ${ }^{5}$
}

Received: November 26, 2016 - Accepted: December 14, 2016

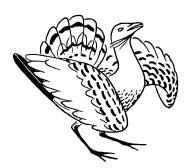

Andrea Harnos, Péter Fehérvári, Imre Sándor Piross, Zsolt Karcza, Nóra Ágh, Szilvia Kovács \& Tibor Csörgő 2016. Exploratory analyses of migration timing and morphometrics of the Pied Flycatcher (Ficedula hypoleuca). - Ornis Hungarica 24(2): 109-126.

as source of information. However, basic descriptive statistics of collected data are rarely provided. In order to fill this gap, here we present the first item of a series of exploratory analyses of migration timing and body size measurements of the most frequent Passerine species at a ringing station located in Central Hungary (1984-2015). First, we give a concise description of foreign ring recoveries of the Pied Flycatcher in relation to Hungary. We then shift focus to data of 2860 individuals deriving from the ringing station, where birds have been trapped, handled and ringed with standardized methodology since 1984. Timing is described through annual and daily capture and recapture frequencies and their descriptive statistics. We show annual mean arrival dates within the study period and we present the cumulative distribution of first captures with stopover durations. We present the distributions of wing, third primary, tail length and body mass, and the annual means of these variables. Furthermore, we show the distribution of individual fat and muscle scores, and the distribution of body mass within each fat score category. We distinguish migration periods (spring and autumn), age (i.e. juveniles and adults) and sex groups. Our aim is to provide a comprehensive overview of the analysed variables. However, we do not aim to interpret the obtained results, merely draw attention to interesting patterns, that may be worth exploring in detail. Data used here are available upon request for further analyses.

Keywords: Ócsa Bird Ringing Station, wing, third primary, tail length, body mass, fat, muscle, bird banding, capture-recapture, long term data, meta-analyses

Összefoglalás Madártani tanulmányokban gyakran elemeznek hosszútávú madárgyưrúzési adatsorokat, de az alapvetô leíró statisztikák és exploratív elemzések általában nem hozzáférhetőek. E hiányt pótolandó, cikksorozatot indítunk, melyben egy közép-magyarországi gyưrúző állomáson leggyakrabban előforduló énekesmadár fajok vonulás időzítésének és testméreteinek exploratív elemzéseit közöljük (1984-2015). A sorozat az elsô tagjaként szolgáló jelen cikkben először áttekintjük a kormos légykapó magyar gyứrús külföldi és külföldi gyưrűs magyarországi megkerüléseit, majd rátérünk a faj egy magyarországi, 1984 óta standard módszerekkel dolgozó gyưrúzőállomásról származó 2860 egyedétől származó adatának elemzésére. Az időzítés jellemzéséhez az éves és a napi átlagos első megfogások és visszafogások leíró statisztikái mellett megmutatjuk az évenkénti átlagos érkezési időket és azok változását. Az éven belüli időzítést az első megfogások kumulatív eloszlásával ábrázoljuk feltüntetve a tartózkodási időket is. Közöljük a szárnyhossz, a harmadik evező hossz, a farokhossz és testtömeg leíró statisztikáit. Ábrákon bemutatjuk ezen változók éves átlagait, a zsír- és izomkategóriák gyakorisági eloszlását, valamint a testtömegek eloszlását zsírkategóriák szerinti bontásban. Az elemzésben elkülönítjük az egyes vonulási időszakokat (tavasz, ôsz), a korcsoportokat (fiatal, öreg), illetve az ivarokat (hím, tojó). Célunk a vizsgált változók átfogó bemutatása és a bennük található mintázatok feltárása volt az eredmények interpretálása nélkül. Kérésre a cikkhez felhasznált adatsort rendelkezésre bocsátjuk. 
Kulcsszavak: Ócsai Madárvárta, szárnyhossz, harmadik evező hossza, farokhossz, testtömeg, zsír, izom, madárgyưrúzés, hosszútávú adatsor, meta-analízis

\footnotetext{
${ }^{I}$ Department of Biomathematics and Informatics, University of Veterinary Medicine, 1078 Budapest, István utca 2., Hungary, e-mail: harnos.andrea@univet.hu

${ }^{2}$ Department of Zoology, Hungarian Natural History Museum, 1088 Budapest, Baross utca 13., Hungary

${ }^{3}$ Hungarian Bird Ringing Center, BirdLife Hungary, 1121 Budapest, Költó utca 21., Hungary

${ }^{4}$ Department of Ecology, University of Veterinary Medicine, 1078 Budapest, István utca 2., Hungary

${ }^{5}$ Department of Anatomy, Cell- and Developmental Biology, Eötvös Loránd University, 1117 Budapest, Pázmány Péter sétány 1/C, Hungary

*corresponding author
}

\section{Introduction}

Bird ringing or banding is one of the principal and oldest methods in use to study various aspects of avian populations (Robinson et al. 2009). Overwhelming volume of data has been collected in over a century of bird ringing, and has been used excessively in a diverse array of disciplines. However, compared to the amount of data available throughout the world, concise descriptive information suitable for meta- or comparative analyses is sporadically available (Gienapp et al. 2007, Harnos et al. 2015a). Though purely descriptive studies are often hard to publish within the framework of current hypothesisfocused science, we feel that such studies may well play an outstanding role in generating new hypotheses for future studies. For this purpose, it is essential that descriptive studies must apply the most appropriate statistical methodologies (Harnos et al. 2015a, 2016). The bulk of currently available ringing data is often derived from large temporal scale projects like permanent ringing stations, where massive amount of individuals of various species are trapped simultaneously (Csörgô et al. 2016). These projects generally apply standardized and similar methodologies in trapping, handling and data collection, thus information derived from these sites is suitable for location-wise comparisons (Schaub \& Jenni 2000, Marra et al. 2004, Schaub et al. 2008, Tøttrup et al. 2010).

Here we present exploratory and descriptive statistics on the migration timing and morphometrics of the Pied Flycatcher between 1984-2015 from a Central European ringing station (Ócsa Bird Ringing Station, Hungary, see Csörgó et al. 2016 for details).

The Pied Flycatcher is a small, insectivorous passerine of the Muscicapidae family. The breeding plumage is sexually dimorphic. The upperparts of males are black contrasting the white forehead, wing patches and underparts, whereas the upperparts of females and juveniles are drab. Pied Flycatchers are polytipical with 4 subspecies, namely $F$. $h$. hypoleuca, $F$. h. sibrica, F. h. iberiae and F. h. speculigera. Plumage varies across races, differing predominantly in upperpart colouration, and in the extent of white in the forehead and wing patches. The breeding distribution ranges from Western North Africa through most of the European continent reaching well into Central Asia. The nominate subspecies is found in continental Europe excluding the Iberian Penninsula where it is replaced by $F$. 
h. iberiae. F. h. sibrica breeds in Siberia, while F. h. speculigera is found in the coastal regions of Western North Africa (Cramp \& Perrins 1993, Taylor 2006).

The Pied Flycatcher is classified as Least Concern in the IUCN Red List, however the European population is seemingly decreasing (BirdLife International 2016). It is a sporadic to rare breeder in Hungary, predominantly found in the Southern Great Plain, Alpine Foothills and Zala Hills (Hadarics \& Zalai 2008, Török 2009). Pied Flycatchers may hybridize with the closely related Collared Flycatcher (Ficedula albicollis) in areas where the two species are sympatric like in Hungary (BirdLife Hungary 2016). Pied Flycatchers inhabit deciduous forests throughout the breeding distribution range where they nest in tree cavities. They constitute model systems of various behavioural disciplines, hence their mating and parental care have been extensively studied (Lundberg \& Alatalo 2010). Their mating system is social monogamy and successive polygyny (i.e. males may be polyterritorial and may mate with multiple females; Haartman 1951, Alatalo et al. 1981, Dale \& Slagsvold 1996). The parental care is generally biparental (Moreno et al. 1995) with variation in male contribution largely depending on the number of female partners (Lifield \& Slagsvold 1990) among other traits.

All subspecies are obligatory long distance, trans-Saharan migrants. In the autumn, Pied Flycathcers migrate between August and September in Europe (Cramp \& Perrins 1993). The large scale spatial pattern of ring recoveries from this season indicate a general south-western bearing with the most important known stopover (refuelling) sites being in South West France, North West Spain and North Portugal (Jones 2002). Birds ringed in Scandinavia and North West Europe are recaptured from the Atlantic coasts of France, Spain and Portugal to the Czech Republic, Austria, North Italy and North West Africa (Bønløkke et al. 2006, Fransson \& Hall-Karlsson 2008, Valkama et al. 2014). Recaptures in the Czech Republic originate mainly from Sweden and Finland, with a handful of Ukrainian and Russian recoveries, including an individual east of the Ural mountain range (Hromádko 2008). The birds are territorial on the stopover sites and accumulate fat reserves for onward migration.

Their wintering grounds are in tropical West Africa, ranging from Guinea to Ghana (Cramp \& Perrins 1993, Salewski et al. 2004). Pied Flycatchers are territorial and show high site fidelity during wintering (Salewski et al. 2002).

Little is known on the spring migration routes in Africa, although in Europe it probably leads further east; over the northern part of the Apennine Peninsula and Central Europe (Cramp \& Perrins 1993, Fransson \& Hall-Karlsson 2008, Spina \& Volponi 2009, Bairlein et al. 2014, Valkama et al. 2014).

It is a common migrant from mid-April to mid-May in spring and from late August until mid-September in autumn in Hungary (Hadarics \& Zalai 2008, Török 2009). Pied Flycathers are regular and common passage migrants at the Ócsa Bird Ringing Station, the source of data analysed in this paper.

Our aim is to provide a comprehensive overview of migration timing, body size measurements and inter-annual changes in these variables. Hopefully, these patterns will help 
formulate research questions and provide information for further higher level analyses. However, we do not aim to interpret the obtained results, merely draw attention to interesting patterns, that may be worth exploring in detail.

\section{Materials and methods}

\section{Bird ringing data}

The Ócsa Bird Ringing Station is situated in Central Hungary (N47.2970, E19.2104) in the Duna-Ipoly National Park in the immediate vicinity of Ócsa town. The study site is characterized by a post-glacial peat bog with mosaic of habitats that include open water surfaces, reedbeds, bushy vegetation and forests. It is situated in a humid continental transitional climate zone (for further details see Csörgő et al. 2016, ocsabirdringing.org ). Birds were trapped with standard mistnets located in standard locations throughout the study period. Trapping effort is seasonal and changed over the years (see Csörgó et al. 2016 for details).

The day of the year of first capture in spring and in autumn separately was considered as arrival (migration) timing of individual birds. Stopover duration was calculated as the difference of within season last and first captures excluding within day recaptures. Biometric measurements were taken following strictly standardized methods (Szentendrey et al. 1979, EURING 2015). Only data of the first captures were used in the analysis. We distinguished first calendar year birds (juveniles) from adults as well as the sexes in both age classes upon plumage characteristics (Cramp \& Perrins 1993, Svensson 1992, Demongin 2016), and we present all results according to these groups. We present data for spring and autumn migratory seasons separately; birds caught before the $145^{\text {th }}$ day of the year were considered to be spring migrants. A total of 2860 Pied Flycatchers were captured and ringed between April and September; 268 males and 176 females in spring, 120 adult males and 196 adult females, 975 juvenile males and 657 juvenile females in autumn (the age or sex of the rest of birds were not defined) in the study period of 1984-2015. This total value constitutes ca. 26\% of the 11,044 Pied Flycatchers ringed in Hungary in this period.

\section{Statistical methods}

To describe daily and yearly capture frequencies and the cumulative distribution of the date of first captures with recaptures, we used the functions of the ringR package (Harnos et al. 2015a). Descriptive tables (mean, median, standard deviation (SD), minimum $(\min )$, maximum $(\max )$ values and sample size $(\mathrm{N}))$ on the timing of migration, stopover duration, the length of wing, third primary and tail, and body mass were created by the data.table package (Dowle et al. 2013), which is highly effective in calculating summary statistics for different groups and subsets. The annual mean values of timing, body mass, wing-, third primary and tail lengths are plotted against time (year) on scatterplots. Loess smooth lines were fitted to highlight trends (Cleveland et al. 1992). The distribution 


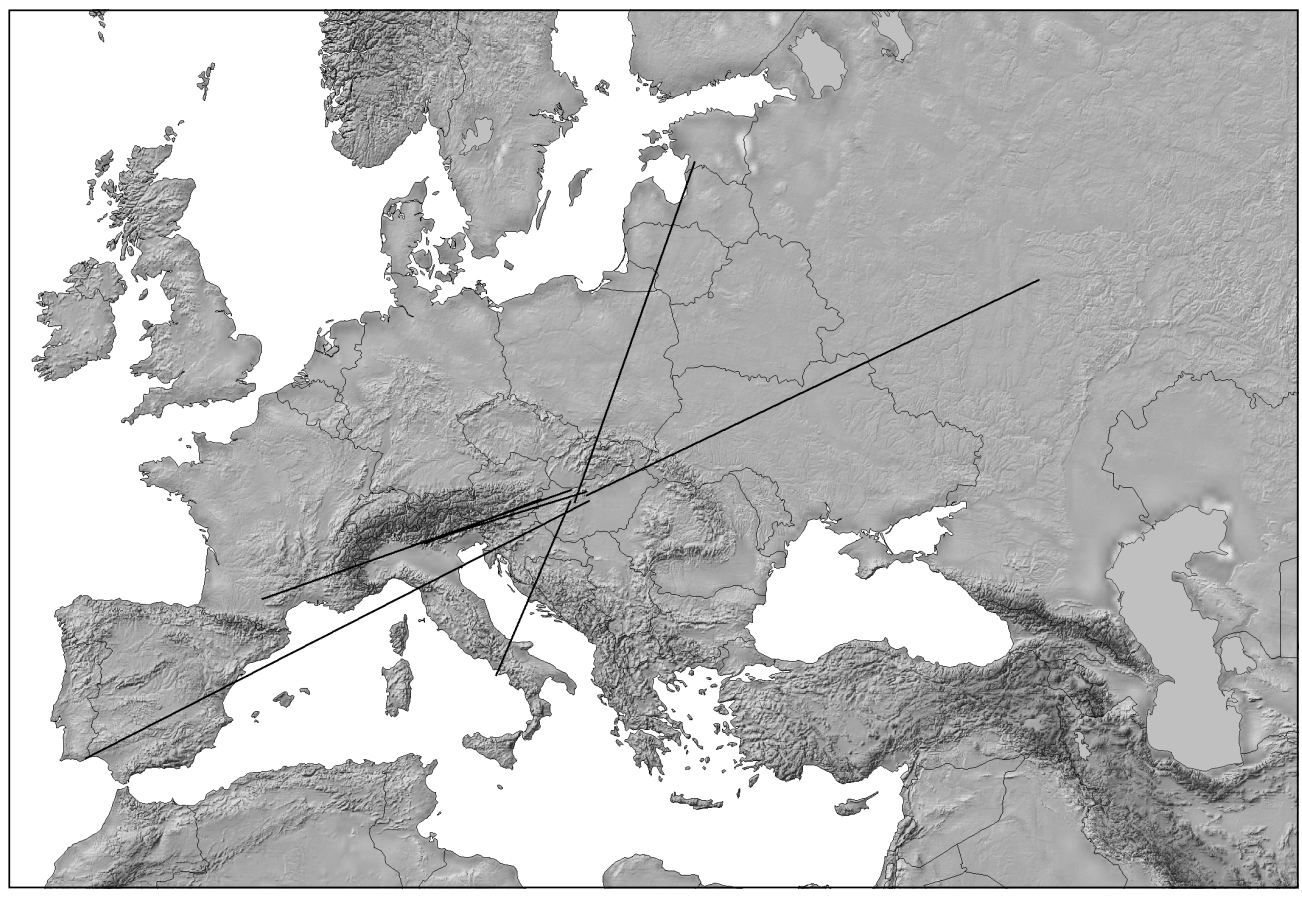

Figure 1. Foreign ring recoveries of Pied Flycatchers. The data of birds ringed in Hungary and recovered abroad and the birds ringed abroad and recovered in Hungary are depicted

1. ábra Magyarországon jelölt és külföldön megkerült, illetve külföldön jelölt és Magyarországon megfogott kormos légykapók

of the same variables were represented with histograms and overplotted smooth histograms. Boxplots were used to show the body mass distribution by fat score categories. Fat and muscle score frequencies are shown using barplots. We distinguished seasons,age and sex groups throughout the analyses. For more details on the analysis, please visit ocsabirdringing.org. All analyses were done in R 3.2.2 (R Core Team 2015).

\section{Results}

A total of 6 foreign recaptures were recorded between 1951 and 2016 in relation to Hungary (Figure 1). Annual capture and recapture frequencies at the study site are shown in Figure 2. Within-year capture and recapture frequencies, together with cumulative distribution of individual first and last captures are depicted in Figure 3, while their respective descriptive statistics are presented in Tables 1-2. Changes in annual mean arrival dates throughout the study period and the distribution of within-year migration timing according to season, age and sex are presented in Figure 4. The trend of annual mean wing lengths and the distribution of wing length measurements according to season, age and sex are shown in Figure 5, while their respective descriptive statistics are presented in Table 3. 

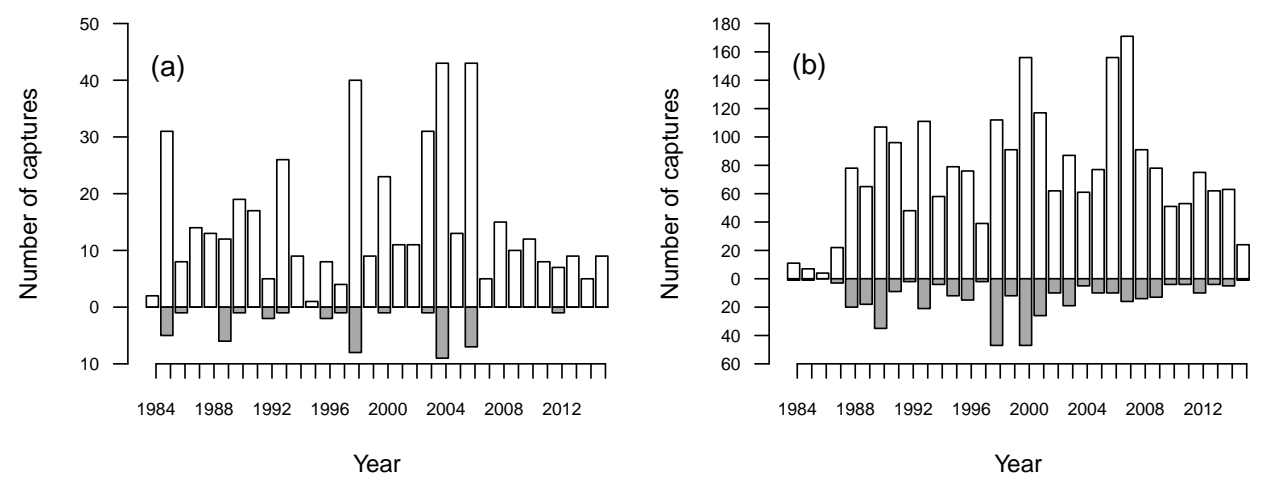

Figure 2. Annual capture (white bars) and recapture (grey bars) frequencies in spring (a), and in autumn (b)

2. ábra Éves fogás (fehér oszlopok) és visszafogás (szürke oszlopok) gyakoriságok tavasszal (a) és ősszel (b)

Third primary length (Figure 6, Table 4), tail length (Figure 7, Table 5) and body mass (Figure 8, Table 6) are presented in a similar fashion. Body mass in relation to season, age and sex and fat scores are visualized with boxplots in Figure 9. Finally, the distribution of fat and muscle scores grouped by season, age and sex can be found in Figure 9 b,d,f and Figure 10.

Table 1. Descriptive statistics of migration timing (day of the year)

1. táblázat A vonulás időzítés (év napja) leíró statisztikái

\begin{tabular}{|l|l|l|l|c|r|r|r|c|}
\hline Season & Age & Sex & Mean & Median & SD & Min & Max & N \\
\hline spring & adult & male & 112.8 & 111 & 8.8 & 90 & 139 & 268 \\
\hline spring & adult & female & 118.5 & 119 & 8.3 & 101 & 139 & 176 \\
\hline autumn & adult & male & 241.2 & 243 & 13.1 & 180 & 276 & 120 \\
\hline autumn & adult & female & 242.9 & 244 & 11.3 & 190 & 275 & 196 \\
\hline autumn & juvenile & male & 237.5 & 238 & 12.3 & 204 & 281 & 975 \\
\hline autumn & juvenile & female & 238.3 & 238 & 12.5 & 202 & 273 & 657 \\
\hline
\end{tabular}

Table 2. Descriptive statistics of stopover duration (day)

2. táblázat A tartózkodási idő (nap) leíró statisztikái

\begin{tabular}{|l|l|l|c|c|c|c|c|c|}
\hline Season & Age & Sex & Mean & Median & SD & Min & Max & N \\
\hline spring & adult & male & 2.3 & 1.0 & 1.9 & 1 & 6 & 12 \\
\hline spring & adult & female & 2.0 & 2.0 & 1.1 & 1 & 4 & 9 \\
\hline autumn & adult & male & 3.6 & 2.0 & 3.6 & 1 & 12 & 9 \\
\hline autumn & adult & female & 3.2 & 1.5 & 4.0 & 1 & 15 & 14 \\
\hline autumn & juvenile & male & 3.8 & 3.0 & 3.2 & 1 & 15 & 98 \\
\hline autumn & juvenile & female & 3.4 & 3.0 & 2.6 & 1 & 13 & 73 \\
\hline
\end{tabular}



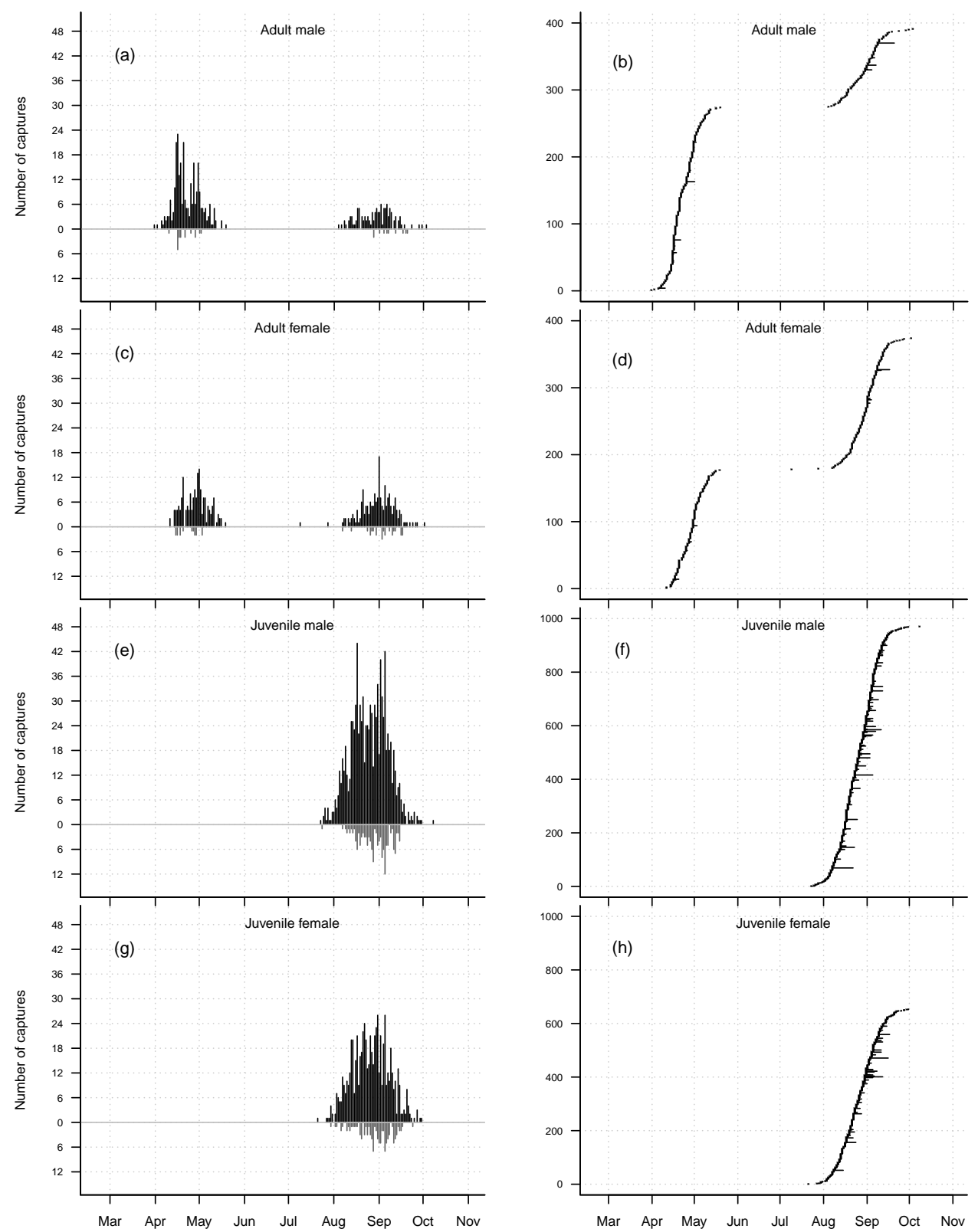

Figure 3. Within-year capture (black bars) and recapture (grey bars) frequencies (a, c, e, g) and cumulative distributions of individual first and last capture dates $(b, d, f, h)$ according to age and sex

3. ábra Éven belüli fogás (fekete oszlopok) és visszafogás (szürke oszlopok) gyakoriságok (a, $c, e, g)$ és az egyedek első és utolsó fogási dátumának kumulatív eloszlása (b, d, f, h) kor és ivar csoportonként 
Table 3. Descriptive statistics of wing length $(\mathrm{mm})$

3. táblázat A szárnyhossz $(\mathrm{mm})$ leíró statisztikái

\begin{tabular}{|l|l|l|c|c|c|c|c|c|}
\hline Season & Age & Sex & Mean & Median & SD & Min & Max & N \\
\hline spring & adult & male & 80.7 & 81 & 1.7 & 76 & 85 & 262 \\
\hline spring & adult & female & 79.3 & 79 & 1.8 & 75 & 85 & 173 \\
\hline autumn & adult & male & 81.4 & 81 & 2.1 & 76 & 86 & 115 \\
\hline autumn & adult & female & 80.0 & 80 & 1.9 & 75 & 86 & 189 \\
\hline autumn & juvenile & male & 80.3 & 80 & 1.8 & 75 & 87 & 952 \\
\hline autumn & juvenile & female & 79.3 & 79 & 1.7 & 75 & 85 & 646 \\
\hline
\end{tabular}

Table 4. Descriptive statistics of third primary length ( $\mathrm{mm}$ )

4. táblázat A harmadik evező hosszának $(\mathrm{mm})$ leíró statisztikái

\begin{tabular}{|l|l|l|c|c|c|c|c|c|}
\hline Season & Age & Sex & Mean & Median & SD & Min & Max & N \\
\hline spring & adult & male & 61.8 & 62 & 1.5 & 58 & 65 & 225 \\
\hline spring & adult & female & 60.7 & 61 & 1.5 & 57 & 64 & 153 \\
\hline autumn & adult & male & 62.1 & 62 & 1.9 & 56 & 66 & 113 \\
\hline autumn & adult & female & 60.9 & 61 & 1.7 & 57 & 65 & 189 \\
\hline autumn & juvenile & male & 61.4 & 61 & 1.7 & 56 & 67 & 951 \\
\hline autumn & juvenile & female & 60.6 & 61 & 1.6 & 56 & 68 & 645 \\
\hline
\end{tabular}

Table 5. Descriptive statistics of tail length $(\mathrm{mm})$

5. táblázat A farokhossz $(\mathrm{mm})$ leíró statisztikái

\begin{tabular}{|l|l|l|c|c|c|c|c|c|}
\hline Season & Age & Sex & Mean & Median & SD & Min & Max & N \\
\hline spring & adult & male & 54.9 & 55 & 1.9 & 49 & 62 & 262 \\
\hline spring & adult & female & 54.3 & 54 & 1.9 & 49 & 60 & 171 \\
\hline autumn & adult & male & 55.5 & 56 & 2.0 & 50 & 62 & 114 \\
\hline autumn & adult & female & 54.6 & 54 & 2.2 & 50 & 60 & 192 \\
\hline autumn & juvenile & male & 54.8 & 55 & 1.9 & 49 & 61 & 946 \\
\hline autumn & juvenile & female & 54.3 & 55 & 1.9 & 49 & 60 & 633 \\
\hline
\end{tabular}

Table 6. Descriptive statistics of body mass (g)

6. táblázat A testtömeg $(\mathrm{g})$ leíró statisztikái

\begin{tabular}{|l|l|l|c|c|c|c|c|c|}
\hline Season & Age & Sex & Mean & Median & SD & Min & Max & N \\
\hline spring & adult & male & 12.8 & 12.8 & 1.0 & 10.9 & 15.0 & 256 \\
\hline spring & adult & female & 12.8 & 12.7 & 0.9 & 10.7 & 14.9 & 166 \\
\hline autumn & adult & male & 12.8 & 12.8 & 0.9 & 10.9 & 15.6 & 116 \\
\hline autumn & adult & female & 12.5 & 12.5 & 0.9 & 10.3 & 15.0 & 188 \\
\hline autumn & juvenile & male & 12.6 & 12.5 & 1.0 & 10.0 & 18.6 & 943 \\
\hline autumn & juvenile & female & 12.4 & 12.3 & 0.9 & 10.3 & 17.7 & 630 \\
\hline
\end{tabular}



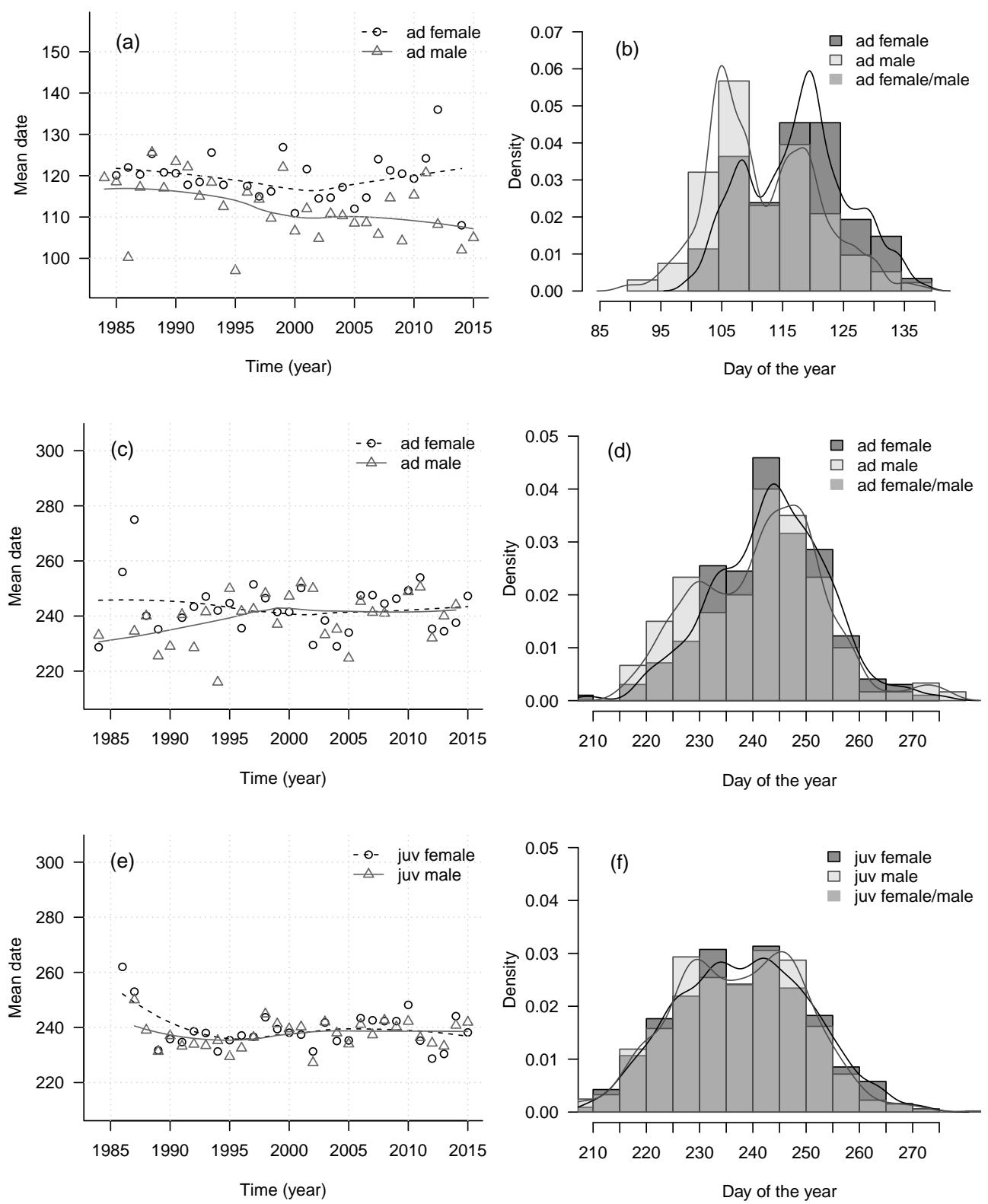

Figure 4. Annual mean migration timing (day of the year) throughout the study period and histograms/smoothed histograms of timing in spring $(a-b)$ and in autumn (c-f)

4. ábra Az éves átlagos vonulás időzítés (év napja) a vizsgálati időszakban és az időzítés hisztogramja/simított hisztogramja tavasszal (a-b) és ősszel (c-f) 

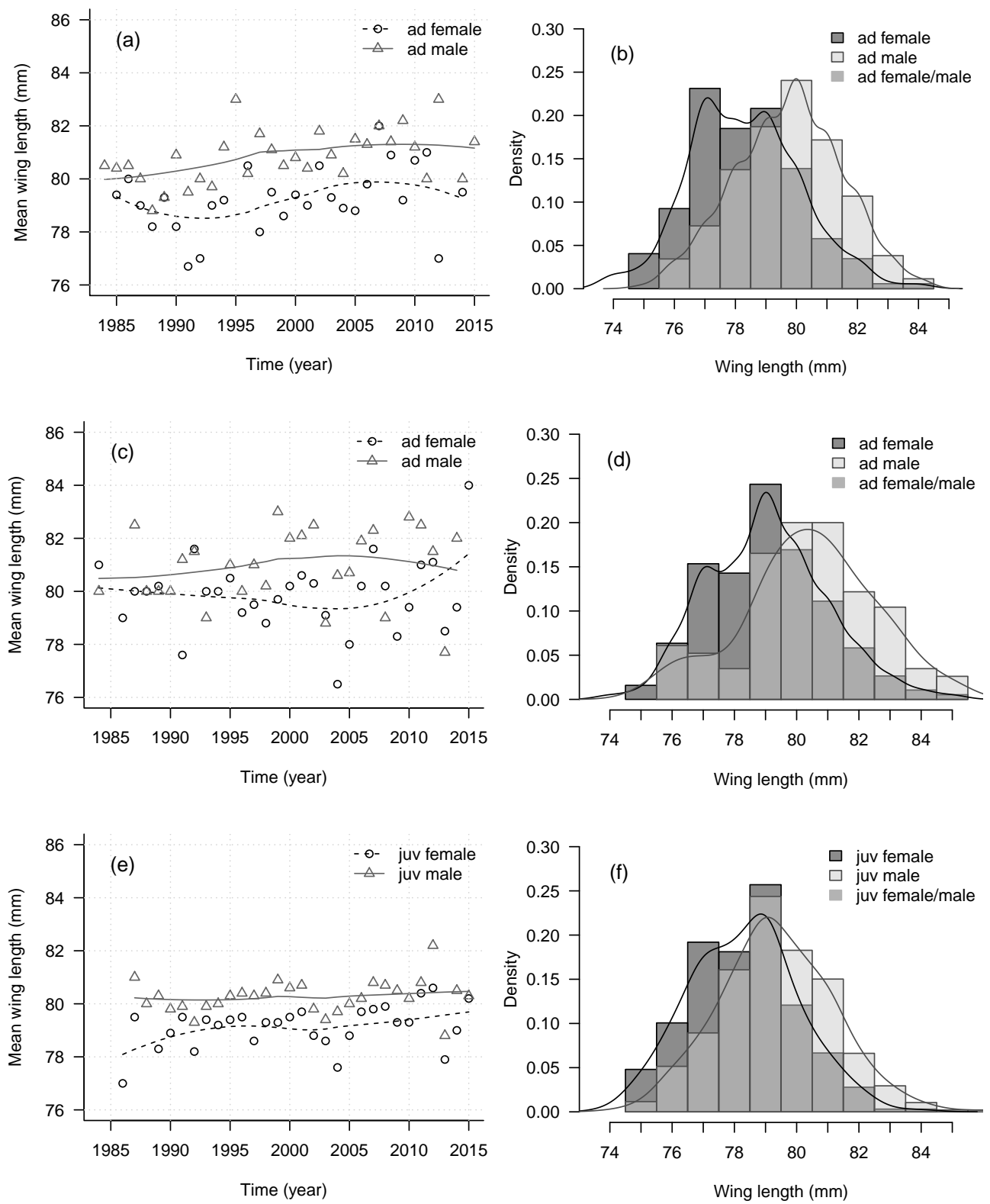

Figure 5. Annual mean wing length $(\mathrm{mm})$ throughout the study period and histograms/smoothed histograms of wing length in spring (a-b) and in autumn (c-f)

5. ábra Az éves átlagos szárnyhossz $(\mathrm{mm})$ a vizsgálati időszakban és a szárnyhossz hisztogramja/simított hisztogramja tavasszal (a-b) és ősszel (c-f) 

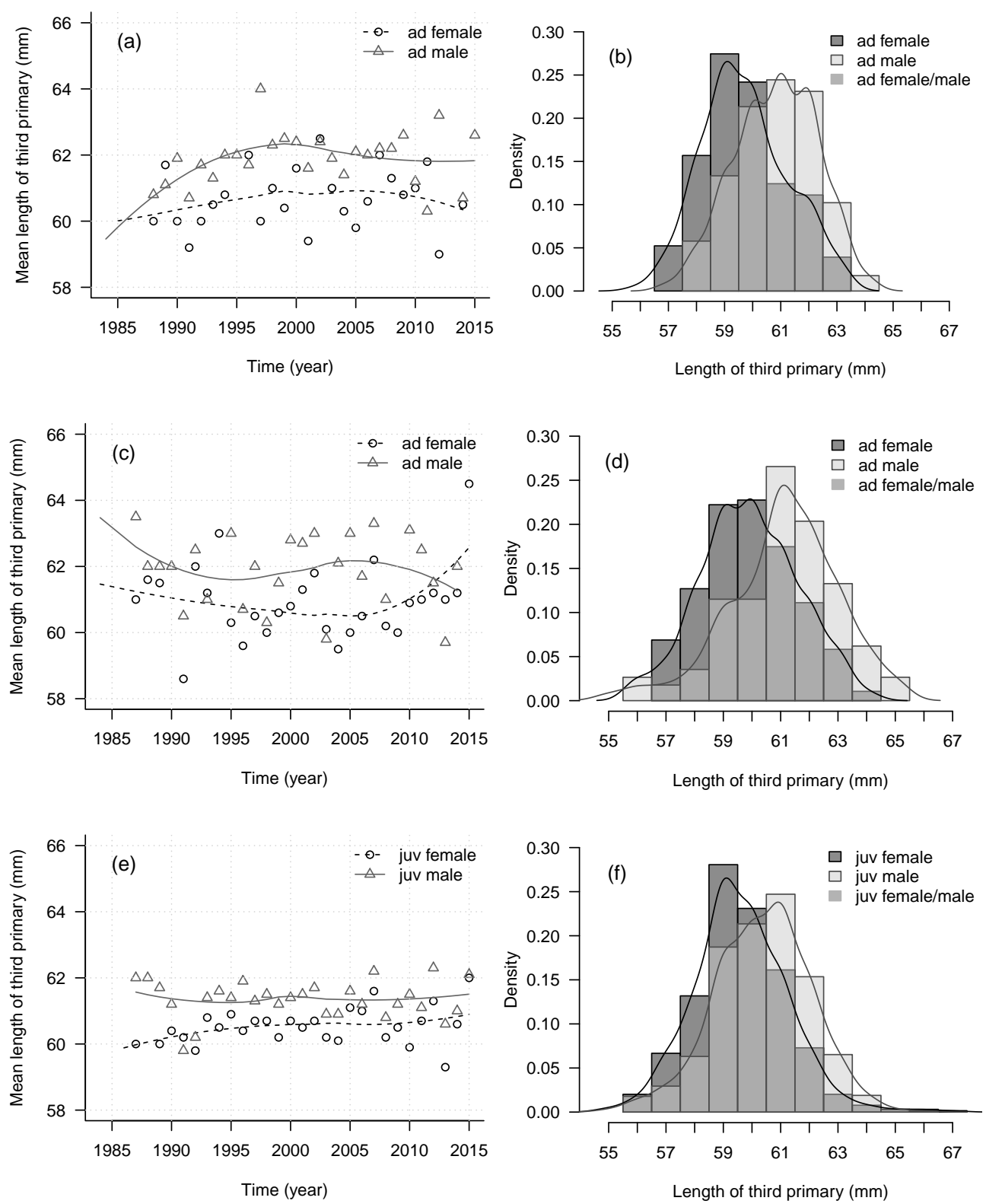

Figure 6. Annual mean third primary length $(\mathrm{mm})$ throughout the study period and histograms/smoothed histograms of third primary length in spring $(a-b)$ and in autumn (c-f)

6. ábra Az éves átlagos harmadik evező hossz $(\mathrm{mm})$ a vizsgálati időszakban és a harmadik evező hosszának hisztogramja/simított hisztogramja tavasszal (a-b) és ősszel (c-f) 

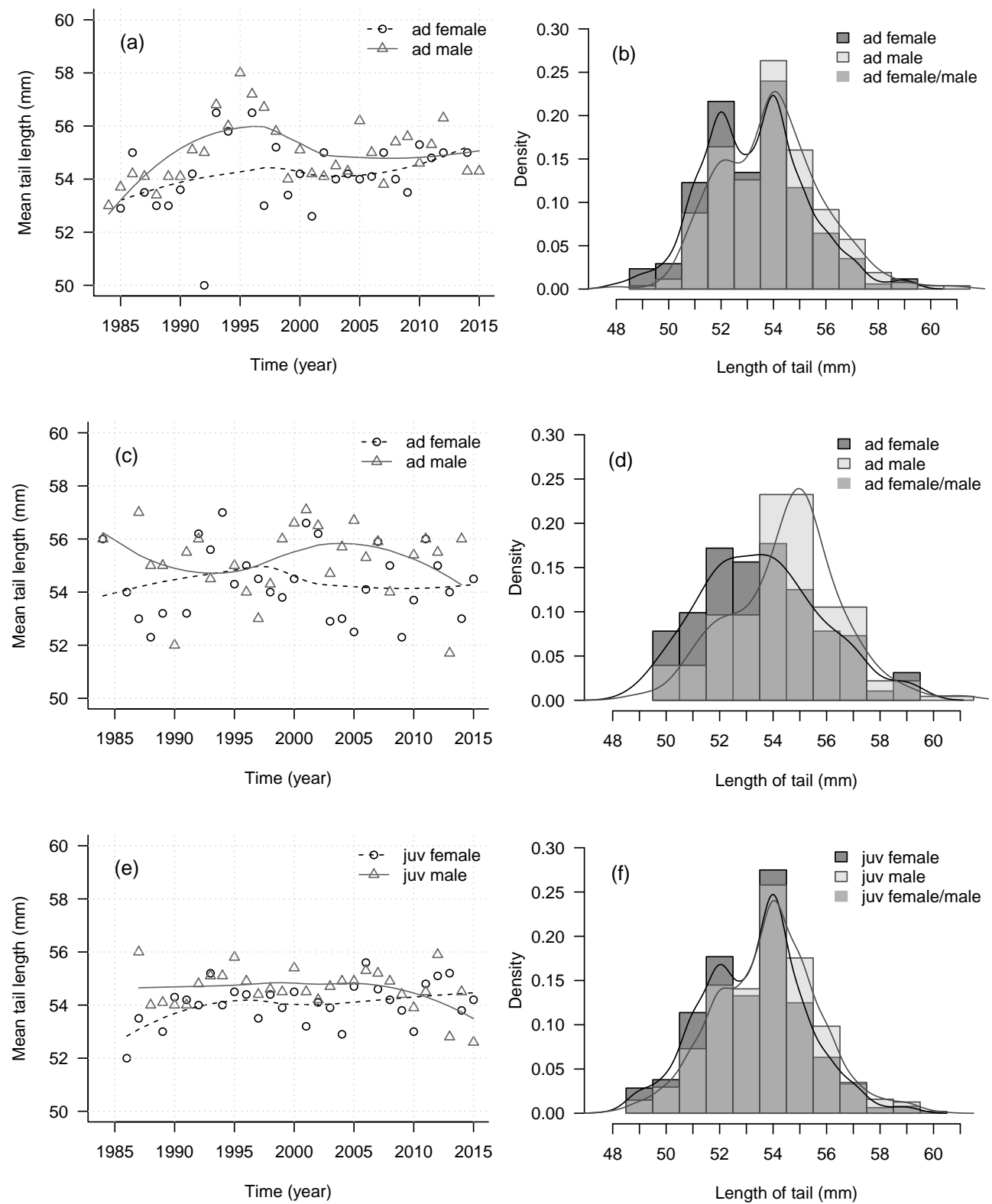

Figure 7. Annual mean tail length $(\mathrm{mm})$ throughout the study period and histograms/smoothed histograms of third primary length in spring $(a-b)$ and in autumn (c-f)

7. ábra Az éves átlagos farokhossz $(\mathrm{mm})$ a vizsgálati időszakban és a farokhossz hisztogramja/simított hisztogramja tavasszal $(a-b)$ és ősszel (c-f) 

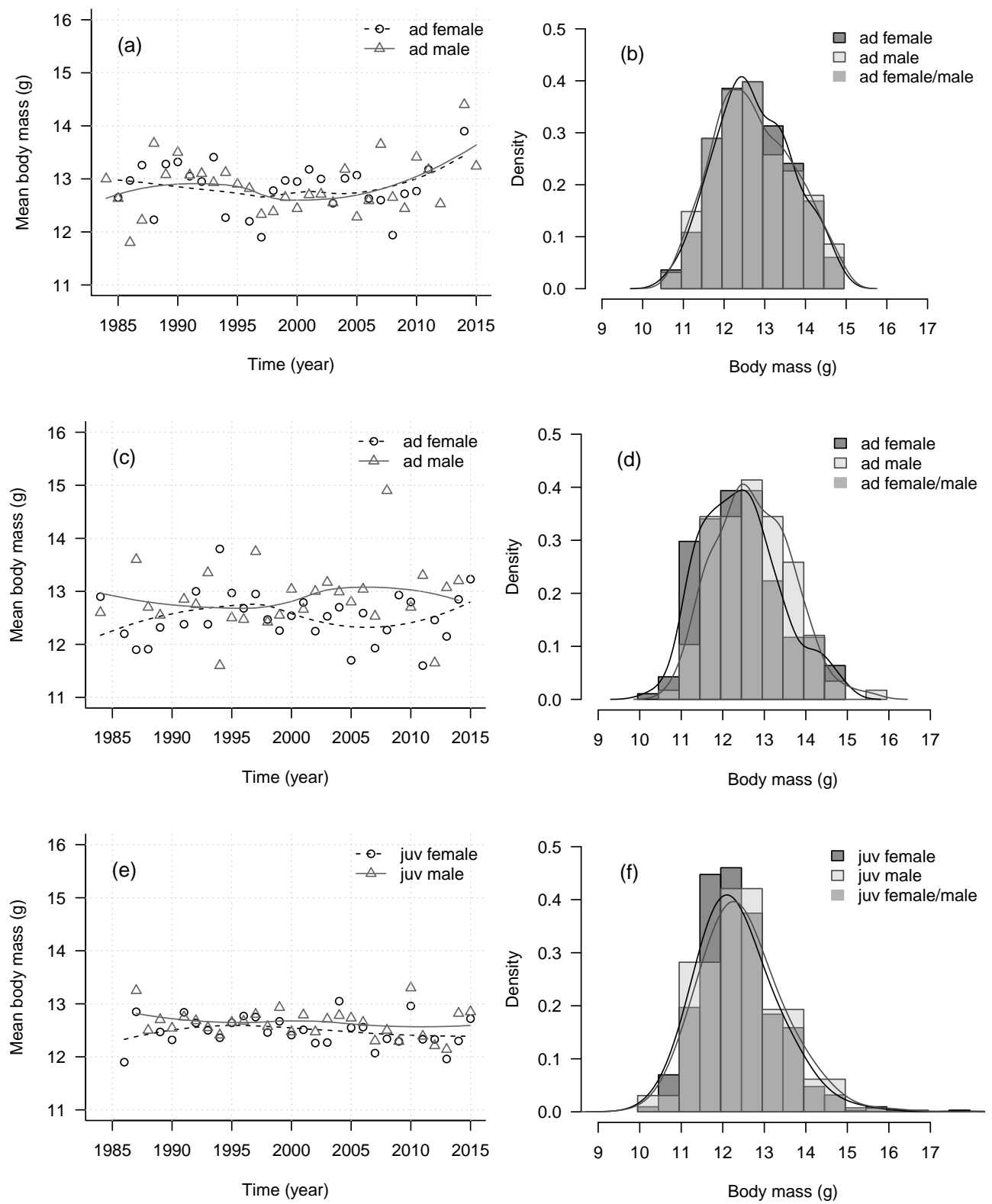

Figure 8. Annual mean body mass $(\mathrm{g})$ throughout the study period and histograms/smoothed histograms of body mass in spring (a-b) and in autumn (c-f)

8. ábra Az éves átlagos testtömeg ( $\mathrm{g}$ ) a vizsgálati időszakban és a testtömeg hisztogram$\mathrm{ja}$ /simított hisztogramja tavasszal (a-b) és ősszel (c-f) 

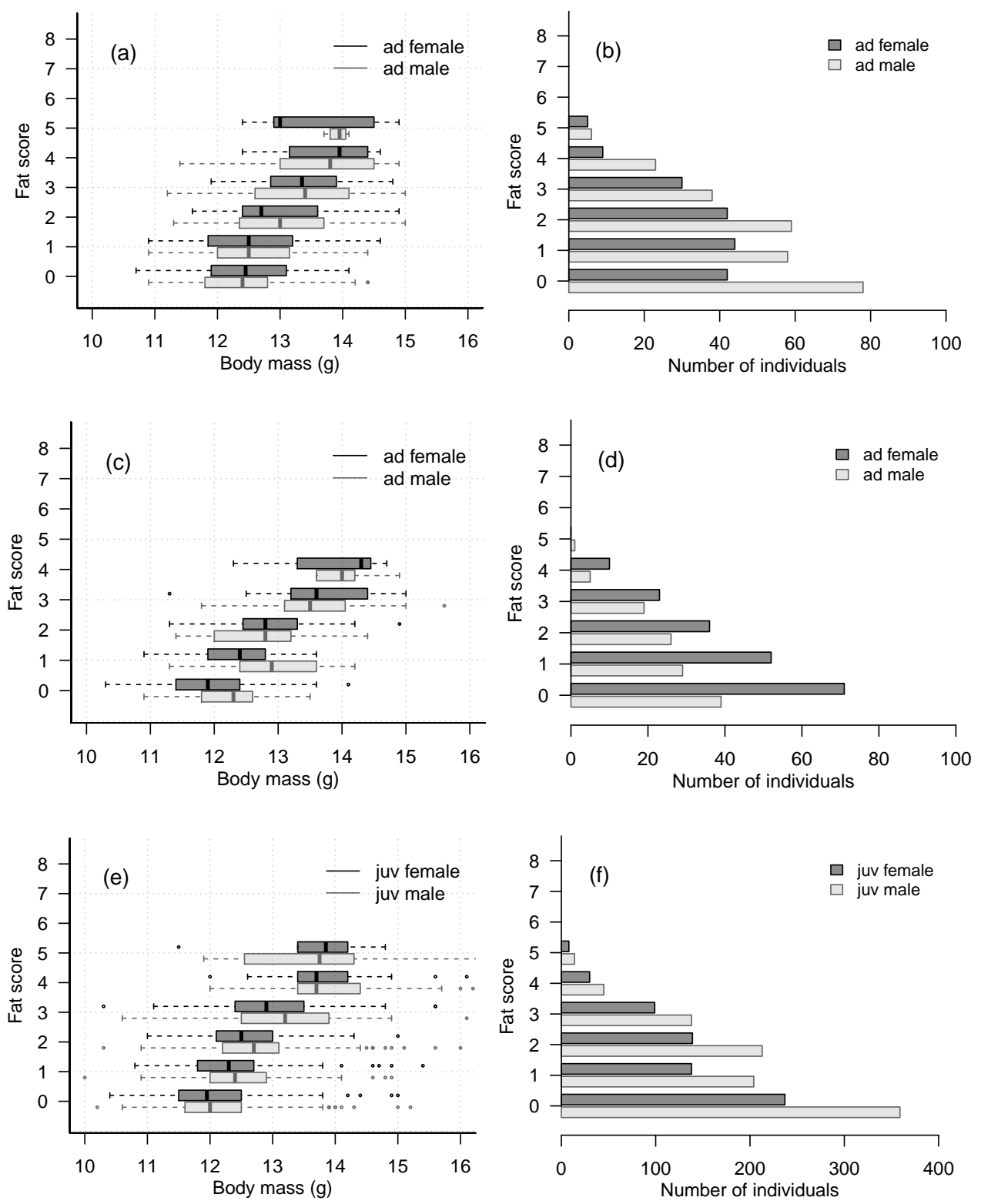

Figure 9. Boxplots of body mass according to fat score, and fat score frequencies in spring $(a-b)$ and in autumn (c-f)

9. ábra A testtömeg boxplot-ja zsírkategóriánként és a zsírkategóriák gyakoriságai tavasszal $(a-b)$ és ősszel (c-f) 

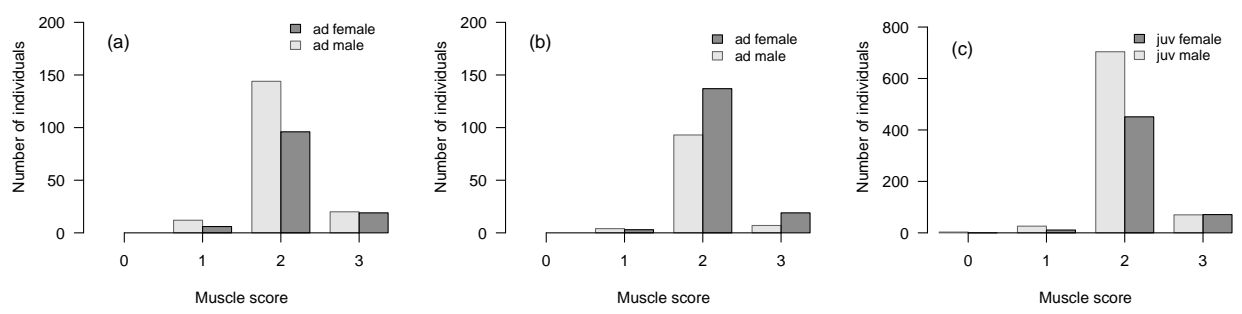

Figure 10. Muscle score frequencies in spring (a) and in autumn (b-c) 10. ábra Izom kategória gyakoriságok tavasszal (a) és ősszel $(b-c)$

\section{Discussion}

The exploratory analyses of timing and morphometrics of the Pied Flycatcher revealed several patterns of interest. Apparently, there is considerable variation in inter-annual capture and recapture frequencies (Figure $2 a, b$ ) with disproportionally more recaptures (Figure $2 a, b$ ) and longer stopover duration (Figure $3 b, d, f, h$, Table 2) in autumn. Evidently, the lack of captures of all age groups during the breeding season corroborates that there is no local breeding population at the study site (Figure $2 a, c$ ). We have previously shown biased sex ratios within migration waves (Harnos et al. 2015b) that are clearly visible from the descriptive statistics (Table 1) and from the fat and muscle score distributions (Figures 9-10).

Migration timing in spring shows indications of increased protandry (Harnos et al. 2015c) and that the distribution of arrival timing in spring of both sexes is seemingly bimodal (Figure $4 \mathrm{~b}$ ). On the other hand, this pattern is not characteristic of the autumn migration timing. In general, wing-, third primary and tail length descriptive statistics (Tables 3-5) show that males have larger mean and median values, which is more apparent when viewing the distributions of these variables (Figures 5-7 b,d). However, sex-specific differences in histogram shapes seem to decrease in case of juveniles (Figures 5-7f). Contrastingly, body mass descriptive statistics and distributions show hardly any sex-specific differences across age groups and seasons (Table 6, Figure 8 b,d,f).

Our results show that comprehensive exploratory analyses may reveal intriguing patterns, which may be investigated in more detail in the future. We however emphasize that although the temporal extent of the data reported here is considerably large, all information presented here derives from a single location and thus has to be interpreted accordingly. Nonetheless, we hope that our results will help researchers conducting comparative or meta-analyses with baseline data and may also encourage others to report their data in a similar fashion. We also seek cooperation with interested parties and are willing to share all data reported here. Please contact the corresponding author for details. 


\section{Acknowledgments}

The authors express their gratitude for the work of all the volunteers who collected data at the Ócsa Bird Ringing Station throughout the years. We are grateful for our colleagues especially for Márton Demeter - who helped us develop the codes and for Lajos Rózsa and János Kis, who helped us improve the manusript. This work was supported by the National Scientific Research Fund of Hungary (OTKA under Grant No. 108571).

\section{References}

Alatalo, R. V., Carlson, A., Lundberg, A. \& Ulfstrand, S. 1981. The conflict between male polygamy and female monogamy: the case of the Pied Flycatcher Ficedula hypoleuca. - American Naturalist 117(2): 738-753. http://www.jstor.org/stable/2460757?seq=1\#page_scan_tab_contents

Bairlein, F., Dierschke, J., Dierschke, V., Salewski, V., Geiter, O., Hüppop, K., Köppen, U. \& Fiedler, W. 2014. Atlas des Vogelzugs [Bird Migration Atlas]. - AULA-Verlag, pp. 461-463. (in German with English Summary)

BirdLife Hungary 2016. Magyarország madarai: Kormos légykapó [Birds of Hungary, the Pied Flycatcher]. - Magyar Madártani és Természetvédelmi Egyesület [BirdLife Hungary].

http://www.mme.hu/magyarorszagmadarai/madaradatbazis-fichyp, downloaded on 30 November 2016. (in Hungarian)

BirdLife International 2016. Ficedula hypoleuca. - The IUCN Red List of Threatened Species 2016: e.T22709308A87938122. DOI: 10.2305/IUCN.UK.2016- 3.RLTS.T22709308A87938122.en

Bønløkke, J., Madsen, J. J., Thorup, K., Pedersen, K. T., Bjerrum, M. \& Rahbek, C. 2006. Dansk trækfugleatlas [Danish Bird Migration Atlas]. - Rhodos, Humlebæk, pp. 686-689. (in Danish with English Summary)

Cleveland, W. S., Grosse, E. \& Shyu, W. M. 1992. Local regression models. - In: Chambers, J. \& Hastie, T. (eds.) Statistical Models in S. - Pacific Grove, California, pp. 309-376.

Cramp, S. \& Perrins, C. M. 1993. The Pied Flycatcher. - Oxford University Press, Oxford, pp. 64-86.

Csörgó, T., Harnos, A., Rózsa, L., Karcza, Zs. \& Fehérvári, P. 2016. Detailed description of the Ócsa Bird Ringing Station, Hungary. - Ornis Hungarica 24(2): 91-108. DOI: 10.1515/orhu-2016-0018

Dale, S. \& Slagsvold, T. 1996. Mate choice on multiple cues, decision rules and sampling strategies in female Pied Flycatchers. - Behaviour 133(11): 903-944. DOI: 10.1163/156853996x00305

Demongin, L. 2016. Identification guide to birds in the hand. - Beauregard-Vernon, pp. 243-244.

Dowle, M., Short, T. \& Lianoglou, S. 2013. data.table: Extension of data.frame for fast indexing, fast ordered joins, fast assignment, fast grouping and list columns. - R package version 1.8.10; with contributions from Srinivasan, S., Lianoglou, A. and Saporta, R. http://CRAN.R-project.org/package=data.table

EURING 2015. The EURING Exchange Code 2000 Plus. - The European Union for Bird Ringing, Thetford, U.K. http://www.euring.org/data_and_codes/euring_code_list/index.html

Fransson, T. \& Hall-Karlsson, S. 2008. Svensk Ringmärkningsatlas Vol. 3. [Swedish Bird Ringing Atlas, Vol. 3.]. - Naturhistoriska Riksmuseet \& Sveriges Ornitologiska Förening, Stockholm, pp. 144-148. (in Swedish with English Summary)

Gienapp, P., Leimu, R. \& Merilä, J. 2007. Responses to climate change in avian migration time microevolution versus phenotypic plasticity. - Climate Research 35: 25-35. DOI: $10.3354 / \mathrm{cr} 00712$

Haartman, L. von. 1951. Successive polygamy. - Behaviour 3(1): 256-273. DOI: $10.1163 / 156853951 x 00296$

Hadarics, T. \& Zalai, T. 2008. Nomenclator avium Hungariae - Magyarország madarainak névjegyzéke [An annotated list of the birds of Hungary]. - Magyar Madártani és Természetvédelmi Egyesület, Budapest, p. 199. (in Hungarian) 
Harnos, A., Csörgő, T. \& Fehérvári, P. 2016. Hitchhikers' guide to analysing bird ringing data. Part 2. Ornis Hungarica 24(1): 172-181. DOI: 10.1515/orhu-2016-0010

Harnos, A., Fehérvári, P. \& Csörgő, T. 2015a Hitchhikers' guide to analysing bird ringing data. Part 1. Ornis Hungarica 23(2): 163-188. DOI: 10.1515/orhu-2015-0018

Harnos, A., Lang, Zs., Fehérvári, P. \& Csörgő, T. 2015b Sex and age dependent migration phenology of the Pied Flycatcher in a stopover site in the Carpathian Basin. - Ornis Hungarica 23(2): 10-19. DOI: 10.1515/orhu-2015-0010

Harnos, A., Nóra, Á., Kovács, Sz., Lang, Zs. \& Csörgő, T. 2015c Increasing protandry in the spring migration of the Pied Flycatcher (Ficedula hypoleuca) in Central Europe. - Journal of Ornithology 156(2): 543-546. DOI: 10.1007/s10336-014-1148-3

Hromádko, M. 2008. Lejsek černohlavý, European Pied Flycatcher. - In: Cepak, J., Klvaňa, P., Škopek, J., Schröpfer, L., Jelínek, M., Hořák, D., Formánek, J. \& Zárybnický, J. (eds) Atlas migrace ptákủ České a Slovenské republiky [Chech and Slovak Bird Migration Atlas]. - Aventinum, Praha, pp. 454-455. (in Slovakian with English Summary)

Jones, P. 2002. Pied Flycatcher. - In: Wernham, C., Toms, M., Marchant, J. H., Clark, J., Siriwardena, G. $\&$ Baillie, S. R. (eds) The Migration Atlas: Movements of the Birds of Britain and Ireland. - British Trust for Ornithology, pp. 584-586.

Lifield, J. T. \& Slagsvold, T. 1990. Manipulations of male parental investment in polygynous Pied Flycatchers, Ficedula hypoleuca. - Behavioral Ecology 1(1): 48-54. DOI: 10.1093/beheco/1.1.48

Lundberg, A. \& Alatalo, R. V. 2010. The Pied Flycatcher. - T \& AD Poyser Ltd., London, U.K.

Marra, P. P., Francis, C. M., Mulvihill, R. S. \& Moore, F. R. 2004. The influence of climate on the timing and rate of spring bird migration. - Oecologia 142(2): 307-315. DOI: 10.1007/s00442-004-1725-x

Moreno, J., Cowie, R. J., Sanz, J. J. \& Williams, R. S. R. 1995. Differential response by males and females to brood manipulations in the Pied Flycatcher: Energy expenditure and nestling diet. - Journal of Animal Ecology 64(6): 721-732. DOI: 10.2307/5851

R Core Team 2015. R: A Language and Environment for Statistical Computing. - R Foundation for Statistical Computing, Vienna, Austria https://www.R-project.org/

Robinson, R. A., Julliard, R. \& Saracco, J. F. 2009. Constant effort: Studying avian population processes using standardised ringing. - Ringing \& Migration 24(3): 199-204. DOI: 10.1080/03078698.2009.9674392

Salewski, V., Altwegg, R., Erni, B., Falk, K. H., Bairlein, F. \& Leisler, B. 2004. Moult of three Palaearctic migrants in their West African winter quarters. - Journal of Ornithology 145(2): 109-116. DOI: 10.1007/s10336-004-0020-2

Salewski, V., Bairlein, F. \& Leisler, B. 2002. Different wintering strategies of two Palearctic migrants in West Africa - a consequence of foraging strategies? - Ibis 144(1): 85-93. DOI: 10.1046/j.0019-1019.2001.00007.x

Schaub, M. \& Jenni, L. 2000. Fuel deposition of three passerine bird species along the migration route. Oecologia 122(3): 306-317. DOI: 10.1007/s004420050036

Schaub, M., Jenni, L. \& Bairlein, F. 2008. Fuel stores, fuel accumulation, and the decision to depart from a migration stopover site. - Behavioral Ecology 19(3): 657-666. DOI: 10.1093/beheco/arn023

Spina, F. \& Volponi, S. 2009. Atlante della migrazione degli uccelli in Italia. Vol. 2.: Passeriformi [Italian Bird Migration Atlas Vol. 2.: Passeriformes]. - Ministero dell'Ambiente e della Tutela del Territorio e del Mare, Roma (Italy) ISPRA, pp. 388-231. (in Italian with English Summary)

Svensson, L. 1992. Identification Guide to European Passerines - Ugga, Stockholm, $4^{\text {th }}$ ed., pp. 227-231.

Szentendrey, G., Lövei, G. \& Kállay, Gy. 1979. Az Actio Hungarica madárgyưrűző tábor mérési módszerei [Measuring methods in the bird ringing camps of Actio Hungarica]. - Állattani Közlemények 66: 161-166. (in Hungarian)

Taylor, P. B. 2006. European Pied Flycatcher. - In: del Hoyo, J., Elliott, A. \& Christie, D. A. (eds.) Handbook of the Birds of the World, Vol. 11. - Lynx Edicion Publications, pp. 129-30. 
Török, J. 2009. Pied Flycatcher. - In: Csörgő, T., Karcza, Zs., Halmos, G., Magyar, G., Gyurácz, J., Szép, T., Bankovics, A., Schmidt, A. \& Schmidt, E. (eds.) Magyar madárvonulási atlasz [Hungarian Bird Migration Atlas]. - Kossuth Kiadó Zrt., Budapest, pp. 537-538. (in Hungarian with English Summary)

Tøttrup, A. P., Rainio, K., Coppack, T., Lehikoinen, E., Rahbek, C. \& Thorup, K. 2010. Local temperature fine-tunes the timing of spring migration in birds. - Integrative and Comparative Biology 50(3): 293-304. DOI: $10.1093 /$ icb/icq028

Valkama, J., Saurola, P., Lehikoinen, A., Lehikoinen, E., Piha, M., Sola, P. \& Velmala, W. 2014. Suomen Rengastusatlas. Osa II. [The Finnish Bird Ringing Atlas Vol. II.]. - Finnish Museum of Natural History and Ministry of Environment, Helsinki, pp. 542-551. (in Finnish with English Summary)

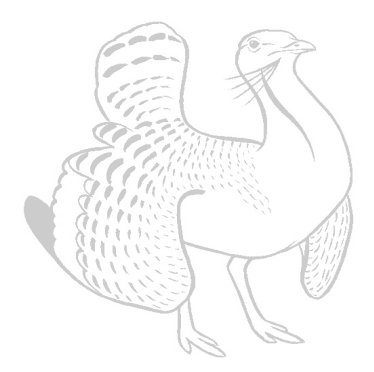

